\title{
Pengaruh Teman Sebaya Terhadap Kemampuan Kognitif Siswa Berkesulitan Belajar Pada Pembelajaran IPA
}

\author{
Margaretha Ordo Servitri \\ Program Studi PGSD STKIP Bina Insan Mandiri Surabaya \\ margarethaordo@stkipbim.ac.id
}

\begin{abstract}
Background of this study was that every learning proces in class commonly found children who had difficulties in learning. The form of difficuties of every student were different, while the learning which were commonly conducted by the teachers in schools still using speech method and excercises only individually so that this cause the learning process only focused on teacher and made the students got difficulties in learning being under-developed in comprehending material of study.This matter could cause the student's afektive skill getting difficulties in learning became low. Through groups of the peer group, those children would be be more motivated to study so that they could solve their learning disability. This study aimed to clarify the influence of the peer group the student's afektive skill who got learning disability in Science (IPA) learning.This study used quantitative research metodology with the type of descriptive research method. The data analysis result showed $t_{\text {count }}(4.540)>t_{\text {tabel }}(2.086)$ that can be taken that Ho decision was refused. So it can be concluded that the peer group has positive effect toward the student's afektive skills who had learning disability.
\end{abstract}

Keyword: peer group, Science learning, student's afektive skill with learning disability

\section{PENDAHULUAN}

Awal dari pendidikan seseorang adalah dari keluarga, maka dari itu peran keluarga juga sangat diperlukan untuk perkembangan kognitif awal seseorang. Keluarga hendaknya memberikan memberikan suatu bekal kepada seorang anak tentang membedakan antara hal yang baik dan buruk. Salah satu hal penting yang perlu diperhatikan adalah bagaimana memberikan atau mendapat pendidikan dengan baik dan benar, agar manusia tidak terjerumus dalam kehidupan yang negatif. Pendidikan mempunyai peranan yang sangat penting dalam menjamin kelangsungan hidup negara, hal ini dikarenakan pendidikan merupakan sarana untuk meningkatkan dan mengembangkan kualitas sumber daya manusia. Melalui pendidikan kehidupan manusia menjadi terarah. Selain peran dari keluarga, terarahnya kehidupan seseorang juga tidak lepas dari pengaruh lingkungan misalnya pengaruh yang ditimbulkan dari hubungan interaksi dengan teman khususnya pada masa anak-anak.

Seorang anak akan mengikuti kebiasaan atau meniru dari teman sebayanya, misalnya dalam hal cara berpakaian, berbicara, dan belajar dengan mengikuti teman sebayanya biasanya seorang anak akan merasa disukai dan diterima dalam pergaulannya dengan kelompok sebayanya. Seorang anak akan merasa senang apabila mereka dapat diterima oleh kelompok sebayanya dan akan merasa tertekan apabila diremehkan oleh kelompoknya. Hubungan yang baik dengan teman sebaya sangat diperlukan agar perkembangan sosial seseorang berjalan normal. Hubungan seseorang dengan teman sebayanya dapat bersifat positif dan negatif. Salah satu fungsi positif teman sebaya hubungan teman sebaya sebagai sumber kognitif (cognitive resources) yaitu untuk memecahkan permasalahan dan memperoleh pengetahuan. Untuk memperoleh pengetahuan seseorang akan menempuh pendidikan baik pendidikan formal maupun pendidikan informal.

Berdasarkan Peraturan Pemerintah Nomor 19 Tahun 2005 tentang Standar Nasional Pendidikan, Bab I Peraturan Umum Pasal 1 Nomor 2 menjelaskan bahwa pendidikan formal adalah jalur pendidikan yang terstruktur dan berjenjang yang terdiri atas pendidikan dasar, pendidikan menengah, dan pendidikan tinggi. Pada setiap jenjang pendidikan memiliki pembelajaran yang sama, dimana pembelajaran tersebut terpusat pada siswa seperti yang dimaksudkan dalam 
Peraturan Pemerintah Nomor 19 Tahun 2005 tentang SNP (Standar Nasional Pendidikan), Pasal 19 Nomor 1 menjelaskan bahwa proses pembelajaran pada satuan pendidikan diselenggarakan secara interaktif, inspiratif, menyenangkan, menantang, memotivasi peserta didik untuk berpartisipasi aktif, serta memberikan ruang yang cukup bagi prakarsa, kreativitas, dan kemandirian sesuai dengan bakat, minat, dan perkembangan fisik serta psikologis peserta didik (Suryosubroto, 2010:96).

Memang tidak dapat dipungkiri peserta didik cenderung menyukai suatu penyelenggaraan pendidikan atau proses pembelajaran yang menyenangkan agar mereka tidak merasa jenuh saat mengikuti proses belajar di kelas. Apabila guru memberikan kegiatan pembelajaran yang interaktif, inspiratif, menyenangkan, dan menantang tentunya dapat memancing siswa untuk aktif pada pembelajaran di kelas, dengan siswa yang aktif maka pembelajaran akan berjalan dengan efektif.

Setiap kegiatan pembelajaran di kelas sering kali ditemui anak yang mengalami kesulitan belajar. Bentuk kesulitan belajar pada setiap anak juga berbeda-beda, sedangkan pembelajaran yang biasa dilakukan guru di sekolah masih sering menggunakan metode ceramah dan penugasan secara individu saja, sehingga hal ini menyebabkan kegiatan pembelajaran hanya berpusat pada guru dan membuat siswa yang mengalami kesulitan belajar menjadi tertinggal dalam memahami materi pembelajaran.

Hal ini mengakibatkan kemampuan kognitif siswa yang mengalami kesulitan belajar menjadi rendah. Guru juga merasa bingung untuk melatih kemampuan kognitif siswa tersebut karena apabila dihadapkan dengan sebuah pertanyaan atau soal mereka cenderung tidak bisa menjawab dan kurang memahami materi yang disampaikan oleh guru. Kesulitan lainnya adalah siswa cenderung malu untuk bertanya pada guru, tetapi hubungan interaksi dengan teman-temannya sangat baik.

Bersama teman sebayanya siswa dapat belajar dan bermain bersama-sama karena terkadang anak-anak pada usia sekolah dasar senang membentuk kelompok sebaya (peer group) dan senang melakukan hal-hal menarik dengan kelompoknya. Mereka akan saling bertukar pengalaman, pengetahuan, dan belajar budaya yang berbeda sehingga anak yang memiliki kesulitan belajar akan dapat termotivasi dalam belajarnya karena apabila kemampuannya di bawah teman-teman kelompok sebayanya ia pasti akan merasa malu. Hal ini akan membuat kelompok sebaya memberikan suatu pengaruh yang positif bagi anak yang memiliki kesulitan belajar, dan anak-anak yang memiliki kesulitan belajar ini pun tidak perlu merasa malu lagi kepada teman-temannya yang lain.

METODE PENELITIAN

Penelitian ini merupakan penelitian dengan pendekatan kuantitatif dan menggunakan metode penelitian pre eksperimental design dengan model one shot case study. Penelitian ini akan diberikan treatment dan hasilnya akan diobservasi. Melalui observasi dan perhitungan data akan diperoleh hasil yang menunjukkan pengaruh teman sebaya terhadap kemampuan kognitif siswa berkesulitan belajar.

Teknik pengumpulan data pada penelitian ini adalah pertama peneliti melakukan pengambilan data dengan menggunakan kuisioner untuk mengetahui apakah anak-anak kelas III SDN Porodeso memiliki kelompok sebaya dan seberapa banyak siswa yang memiliki kesulitan belajar. Setelah itu peneliti mengumpulkan data hasil belajar yang diperoleh dari hasil ujian akhir sekolah (UAS). Hasil ujian akhir sekolah digunakan untuk mengukur kemampuan kognitif siswa berkesulitan belajar. Kemudian untuk melengkapi data peneliti melakukan wawancara dengan kepala sekolah SDN Porodeso untuk mengetahui profil sekolah SDN Porodeso. Instrumen yang digunakan pada penelitian ini sebelumnya diuji coba pada siswa kelas IV SDN Keting Kecamatan Sekaran Kabupaten Lamongan. Setelah dianalisis menggunakan uji validitas dan uji reliabilitas soal yang tidak valid tidak digunakan dalam penelitian dan soal yang dinyatakan valid digunakan sebagai instrumen pengambilan data. Analisis data yang dilakukan pertama adalah analisis deskriptif yang bertujuan untuk mendiskripsikan sampel (responden) dan soal dari intrumen yang digunakan. Kemudian dilakukan uji statistik yaitu menguji tingkat kenormalan data yaitu dengan menggunakan uji lilifors, karena responden yang diambil kurang dari 30 siswa. Kemudian untuk menguji hipotesis digunakan uji regresi linier sederhana, uji persial (uji t), dan koefisien determinasi untuk mengetahui seberapa besar pengaruh teman sebaya 
terhadap kemampuan kognitif siswa berkesulitan belajar.

\section{HASIL \& PEMBAHASAN}

A. Berdasarkan perhitungan uji validitas dan reliabilitas yang telah dilakukan diperoleh 100 item pertanyaan soal valid. Masingmasing 50 soal valid dari variabel $X$ dan 50 soal valid dari variabel $Y$. Pertanyaan dinyatakan valid karena $\mathrm{r}_{\text {hitung }}$ bernilai lebih besar dari $r_{\text {tabel }}(0.361)$. Butir pernyataan yang sudah dinyatakan valid dalam uji validitas akan ditentukan reliabilitasnya dengan kriteria jika nilai Cronbach's Alpha $>0.70$ maka pertanyaan dikatakan reliabel. Pada tingkat dignifikansi 5\% diketahui koefisien alpha (Cronbach's Alpha) adalah 0.977> 0.60 (reliabel) untuk variabel pengaruh teman sebaya $(\mathrm{X})$, dan $0.972>$ 0.60 (reliabel) untuk variabel siswa berkesulitan belajar.

B. Pengaruh dari teman sebaya pada penelitian ini adalah pengaruh yang bersifat positif. Berdasarkan data yang diperoleh peneliti siswa kelas III SDN Porodeso menyatakan mereka senang belajar di sekolah. Mereka merasa senang belajar di sekolah karena belajar bersama dengan teman-teman mereka yang sebaya. Semua anak saling membantu dalam kegiatan belajar dan mengajar baik siswa yang memiliki kesulitan belajar maupun yang tidak memiliki kesulitan belajar. Biasanya seorang anak akan cenderung menyukai belajar dengan teman-teman mereka daripada belajar dengan orang dewasa. Apabila belajar di sekolah dengan temanteman sebaya mereka dapat menjadikan suasana belajar menyenangkan. Selain belajar di sekolah siswa kelas III SDN Porodeso juga sering melakukan belajar bersama kelompok sebaya mereka di rumah. Mereka juga sering melakukan aktifitas bermain dan mengikuti kegiatan ekstrakurikuler bersama-sama misalnya kegiatan pramuka, tari, sepak bola.

C. Sebanyak 5 siswa yang memiliki kesulitan dalam belajar mendapatkan nilai sebesar 80 , sedangkan sebanyak 11 siswa yang memiliki kesulitan belajar mendapatkan nilai sebesar 70. Siswa-siswa berkesulitan belajar tersebut mendapatkan hasil belajar yang baik karena dalam mengerjakan soal tes mereka dibantu oleh sesama siswa atau teman sebaya mereka di kelas.

D. Uji asumsi klasik berguna untuk menentukan layak atau tidaknya data yang akan diuji hipotesisnya. Pada penelitian ini uji asumsi klasik yang digunakan adalah uji normalitas dengan menggunakan uji lilifors. Berdasarkan perhitungan diperoleh $\mathrm{L}_{\text {hitung }}$ $<\mathrm{L}_{\text {tabel }}$ maka data dinyatakan berdistribusi normal, karena data berdistribusi normal maka data layak untuk diuji hipotesisnya.

E. Hasil analisis penelitian dengan uji regresi linier sederhana dengan menggunakan program SPSS 16.0 menunjukkan persamaan regresi sebagai berikut: konstanta (a) $=63.052$ menyatakan bahwa tanpa adanya teman sebaya maka besarnya kemampuan kognitif siswa berkesulitan belajar sebesar 63.052. Koefisien $\mathrm{X}=0.560$ hal ini menunjukkan bahwa variabel teman sebaya memiliki pengaruh positif terhadap kemampuan kognitif anak berkesulitan belajar.

F. Uji $t$ dilakukan untuk mengetahui untuk mengetahui apakah penelitian yang dilakukan akan menerima atau menolak hipotesis. Uji $t$ dapat dilakukan dengan kriteria sebagai berikut:

Ho diterima apabila $-\mathrm{t}(\alpha / 2 ; \mathrm{n}-\mathrm{k}) \leq \mathrm{t}$ hitung $\leq \mathrm{t}(\alpha / 2 ; \mathrm{n}-\mathrm{k})$, artinya tidak ada pengaruh antara variabel bebas terhadap variabel terikat.

Ho ditolak apabila thitung $>\mathrm{t}(\alpha / 2 ; \mathrm{n}-\mathrm{k})$ atau $-\mathrm{t}_{\text {hitung }}<-\mathrm{t}(\alpha / 2 ; \mathrm{n}-\mathrm{k})$, artinya ada pengaruh antara variabel bebas terhadap variabel terikat. Teman sebaya adalah sebesar 4.540 dan nilai ttabel 2.086 sehingga $t_{\text {hitung }}>\mathrm{t}_{\text {tabel }}$ atau $4.540>2.086$. melalui persamaan tersebut dapat disimpulkan bahwa ada pengaruh antara variabel bebas terhadap variabel terikat. Artinya terdapat pengaruh teman sebaya terhadap kemampuan kognitif siswa berkesulitan belajar.

G. Pengujian koefisien Determinasi $\left(\mathrm{R}^{2}\right)$ digunakan untuk mengukur seberapa besar kontribusi variabel $\mathrm{X}$ terhadap variabel $\mathrm{Y}$. Apabila nilai koefisien determinasi mendekati satu maka semakin baik kemampuan variabel $\mathrm{X}$ menerangkan variabel $\mathrm{Y}$ sebagaimana $0<\mathrm{R}^{2}<1$. Apabila $\mathrm{R}^{2}$ semakin besar atau mendekati satu, maka pengaruh variabel independen (X) besar terhadap variabel dependen (Y). Sedangkan apabila $\mathrm{R}^{2}$ semakin kecil atau menjauhi satu, maka pengaruh variabel independen (X) kecil terhadap variabel dependen (Y). Berikut merupakan nilai koefisien determinasi $\left(\mathrm{R}^{2}\right)$ pada penelitian ini: $\mathrm{R}=0.712$ artinya hubungan antara variabel Teman Sebaya (X) dan variabel 
kemampuan kognitif siswa berkesulitan belajar (Y) adalah sebesar $71.2 \%$. Adjusted $\mathrm{R}$ Square sebesar 0.483 berarti $48.3 \%$ variabel kemampuan kognitif siswa berkesulitan belajar dapat dijelaskan oleh teman sebaya. Sedangkan sisanya dapat dijelaskan oleh variabel-variabel lain yang tidak diteliti oleh penelitian ini misalnya hubungan interaksi dengan orang tua. Standar error of Estimated (Standar Deviasi) artinya mengukur variasi dari nilai yang diprediksi. Pada penelitian ini standar deviasi sebesar 8.690 .

Hasil data di atas menunjukkan hipotesis yang berbunyi "Ada pengaruh teman sebaya terhadap kemampuan kognitif anak berkesulitan belajar' dapat diterima Sehingga dapat disimpulkan bahwa ada pengaruh berupa pengaruh positif dari teman sebaya terhadap kemampuan kognitif siswa berkesulitan belajar.

\begin{tabular}{|crr}
\multicolumn{3}{c}{ KESIMPULAN \& SARAN } \\
Berdasarkan hasil penelitian dan \\
pembahasan maka peneliti dapat
\end{tabular}
menyimpulkan ada hubungan atau pengaruh positif antara teman sebaya dengan kemampuan kognitif siswa berkesulitan belajar pada pembelajaran IPA (studi pada siswa kelas III SDN Porodeso, Kecamatan Sekaran Kabupaten Lamongan). Semakin tinggi pengaruh teman sebaya maka semakin tinggi pula kemampuan kognitif siswa berkesulitan belajar. Hal ini ditunjukkan dengan hasil analisis regresi dengan thitung $>t_{\text {tabel }}$ atau ditunjukkan dengan angka $4.540>2.086$. Pengaruh teman sebaya bersifat positif karena teman sebaya dapat memotivasi teman yang lain untuk belajar sehingga kemampuan kognitif siswa berksulitan belajar menjadi lebih baik daripada sebelumnya. Hubungan antara variabel Teman Sebaya (X) dan variabel kemampuan kognitif siswa berkesulitan belajar (Y) sebesar $71.2 \%$.

Berdasarkan kesimpulan hasil penelitian, maka beberapa saran yang dapat ditujukan pada beberapa pihak yaitu sebagai berikut: kepada pihak sekolah perlu mengadakan suatu kegiatan sekolah yang positif untuk siswasiswanya. Selain itu perlu juga membimbing siswa-siswa dalam kelompok sebaya agar mereka memiliki sifat-sifat positif dan tidak melakukan hal-hal yang negatif. kepada pihak guru dalam kegiatan pembelajaran hendaknya menggunakan pembelajaran secara berkelompok. Hal ini dimaksudkan untuk memanfaatkan kelompok sebaya sebagai sarana belajar untuk mengatasi kesulitan belajar pada siswa.

Kepada pihak orang tua diharapkan mereka dapat mengawasi dan membimbing anak-anaknya agar tidak melakukan tindakan yang negatif. Apabila diketahui anak mereka memiliki kelompok sebaya maka hendaknya orangtua mengenal teman-teman dari anak mereka dan membantu mengarahkan mereka ke kegiatan yang positif. Selain itu hendaknya orangtua dapat membimbing anaknya dalam belajar. Apabila mereka tidak bisa membimbing maka hendaknya mereka memotivasi anak-anaknya agar belajar bersama dengan teman-temannya. Siswa hendaknya saling bekerjasama dalam hal belajar dan saling membantu satu sama lain baik dalam mengerjakan tugas sekolah, melakukan kegiatan sekolah, dan lain-lain. Bagi siswa yang memiliki kemampuan kognitif tinggi hendaknya mau membantu teman-teman mereka yang memiliki kesulitan belajar atau masalah dalam memahami materi pelajaran.

\section{DAFTAR PUSTAKA}

Ahmadi, Abu dan Widodo Supriyono.2004. Psikologi Belajar. Jakarta: Rineka Cipta.

Abdurrahman, Mulyono. 2009. Pendidikan Bagi Anak Berkesulitan Belajar. Jakarta: Rineka Cipta.

Arikunto, Suharsimi. 2013. Prosedur Penelitian. Jakarta: Rineka Cipta.

Danim, Sudarwan. 2010. Perkembangan Peserta Didik. Bandung: Alfabeta.

Depdiknas. 2006. KTSP. Jember : Depdiknas Jember

Elizabeth B Hurlock. 2001. Psikologi Perkembangan. Jakarta: Erlangga.

Fatmawati,Ira dkk. 2014. Pedoman Penulisan Karya Ilmiah. Madura : UTM

Irham, Muhammad dan Novan ardi wiyani. 2013. Psikologi Pendidikan Teori dan Aplikasi dalam Proses Pembelajaran. Jogjakarta: Ar Ruzz Media.

Koswara, Deded. 2013. Pendidikan Anak Berkebutuhan Khusus Berkesulitan Belajar Spesifik. Jakarta:PT Luxima Metro Media.

Majid, Abdul. 2013. Strategi Pembelajaran. Bandung: Rosdakarya.

Ormrod, Jeanne Ellis. Jilid 1. Edisi Keenam. 2008. Psikologi Pendidikan Membantu Siswa Tumbuh dan Berkembang. Jakarta: Erlangga.

Patmonodewo, Soemiarti. 2008. Pendidikan Anak Prasekolah. Jakarta: Rineka Cipta. 
Ramansyah, Wanda. 2012. Strategi Pembelajaran. Madura: UTM Press

Sardiman A.M. 2007. Interaksi dan Motivasi Belajar Mengajar. Jakarta : Raja Grafindo Persada.

Siregar, Sofyan. Edisi Pertama. 2013. Metode Penelitian Kuantitatif Dilengkapi Perbandingan Perhitungan Manual \& SPSS. Jakarta : Kencana

Slamet, Santoso. 1999. Dinamika Kelompok. Jakarta : Bumi Aksara.

Slavin, E Robert. 2011. Psikologi Pendidikan Teori dan Praktik. Jakarta: PT Indeks.

Soekanto, Soerjono. 2013. Sosiologi Suatu Pengantar. Jakarta : Rajawali Pers

Somantri, Sutjihati. 2007. Psikologi Anak Luar Biasa. Bandung: Refika Aditama.

Surya, H.M dkk. 2008. Kapita Selekta Kependidikan SD. Jakarta: Universitas Terbuka

Suryosubroto, B. 2010. Beberapa Aspek Dasar-Dasar Kependidikan. Jakarta: Rineka Cipta.

Trianto. 2013. Model Pembelajaran Terpadu. Jakarta: Bumi Aksara.

Wardani, IG.A.K., dkk. 2011. Pengantar Pendidikan Luar Biasa. Jakarta: Universitas Terbuka. 